\title{
Development Processes for Changing the Party System in Slovenia and Montenegro
}

\author{
ELENA NACEVSKA AND NEMANJA STANKOV
}

\section{S sciendo}

Politics in Central Europe (ISSN: 1801-3422)

Vol. 16, No. 3

DOI: $10.2478 /$ pce-2020-0028

\begin{abstract}
This paper explores differences in the party system development of two former Yugoslav republics: Slovenia and Montenegro. Despite sharing a communist institutional system, after that disintegrated Slovenia had a much faster pace of democratic consolidation and economic development than Montenegro. Similarly, the nature of the party competition and party system structure are also quite different. Using a quantitative and descriptive approach applied to the period between 1990 and 2018, we outline patterns of party competition and party system development and explore how they complement the stages of democratisation. We investigate how the comparatively faster democratisation in Slovenia is reflected in the competitive party system with a focus on the ideological divide as the chief source of electoral competition. In contrast, we look at how the prolonged transition in Montenegro is reflected in the closed party system with party competition occurring mainly along ethnic lines.
\end{abstract}

Keywords: political parties, party system, democratic change, typology, Slovenia, Montenegro

\section{Introduction}

Democratisation has captured the minds of many scholars, while much room remains to fully explore the complex processes unravelling in countries in transition. Without analysing the democratisation processes per se, we revisit this general idea by spotlighting the development of party systems across various stages of democratisation in two former Yugoslav republics: Slovenia and Montenegro (for a similar approach, see Pridham 2003; Jungerstam Mulders 
2006). We focus on these two cases because they share important characteristics like a common communist institutional system and a shared past for around 70 years. Further, while the transition to a democracy was triggered by the breaking up of the common communist regime, it led to clear differences in the speed of democratisation and quality of democracy generally. In the paper, we consider significant similarities and differences between the two cases and concentrate on the question of whether these democratisation differences can be identified and linked with development of the party system. By applying this strategy, we hope to isolate the factors and conditions which correlate with effective party competition, party system development and institutionalisation.

The paper explores party system development through two themes which Fink Hafner (2005) states exert a negative impact on the success of countries' democratic transition: institutional (constitutional) and non-institutional factors (socioeconomic). Regarding the institutional setting, the paper begins by briefly considering the transformation of the 'old ruling elites' into newly formed political parties, and the fresh challenges brought to post-communist countries by the fall of communism (Nacevska 2018). Following Linz - Stepan's (1996: 16) observation that the democratic transition has been completed ${ }^{1}$, we look at Slovenia's fast and Montenegro's long transition and show its complementarity with the structure of their party competition and development of their party systems.

Analysis of the institutional differences in rules for establishing new parties follows, especially in electoral systems and how they structure party competition. While both countries nominally conduct their elections under proportional representation rules, the Slovenian system with its unit and district division closely approximates majoritarian competition among individual candidates. Together with ideological party-based competition, the electoral system in Slovenia is complemented by more frequent changes in party elites and a more fragmented party system. We illustrate this point by providing data on party system fragmentation with the effective number of parties, and party system stability with electoral volatility rates. Here the main question is whether the stages of democratic development complement the levels of stability and fragmentation of the party system.

With regard to the second theme of Fink Hafner (2005) (socioeconomic factors), we describe how the initial, fast societal-level bargaining, a clear idea of development held by the Slovenian elites, and party competition structured along ideological lines were quite rapidly followed by a democratic system. On the other hand, the frequent changes in goals held by the elite (federal unity vs. state independence), ethnic division and competition along ethnic cleavage lines were followed by a prolonged transition and consolidation of democracy in Montenegro.

1 The transition is completed when a certain agreement has been achieved in political procedures for electing a government at indirect, free and general elections. 
Moreover, we focus on differences in salient issues in the party competition, i.e. ideology and ethnicity ${ }^{2}$.We argue these differences have been the source of the various internal and external challenges to the power of the ruling elites in these two countries. Here, the relative ethnic unity in Slovenia was followed by party competition on ideological lines, where we outline how this structure is related to external power challenges made to the ruling elites. These external challenges eventually led to the demise of LDS (Liberal Democracy of Slovenia) in 2004. Yet, in Montenegro. ethnic heterogeneity was followed with ethnic voter-party linkages. These ethnic linkages probably explain the fairly stable patterns of electoral support that have so far meant the country's dominant party DPS (Democratic Party of Socialists) enjoys an unrivalled position. Here, the power challenges were internal and arose from a party split in 1997 rather than a competitive political environment. This part of the paper focuses on the question of how cleavage structures (i.e. ideological vs. ethnic) relate to the nature of the party competition and party system in general.

\section{Creating new democracies and building nation-states - case studies of Slovenia and Montenegro}

The Yugoslav federal republic government of Slovenia declared its independence on 25 June 1991, with its declaration only briefly being challenged by the Yugoslav People's Army. Slovenia thereby largely escaped the violence that marked the federation's dissolution. The Constitution that followed in December 1991 established Slovenia as a multiparty parliamentary republic. As the most developed of all the Yugoslav republics - with the most advanced economy, already well integrated into Western European markets, and ethnically the most homogenous of all republics - Slovenia's transition to a democracy was both smooth and quick. This transition was characterised by cooperation and bargaining among the emerging civil society and various new social movements, newly emerging opposition political parties, and existing political elites (Kustec - Henjak 2015). In comparison, Montenegro's almost two-decade-long transition was characterised by the transformation of the ruling elite's political goals. The change was reflected in a turn from a republic that in the early years of the breaking up of Yugoslavia had sought to be a member of a federal state with Serbia, towards an independent Montenegro. This change in political goals in the direction of independence was also followed by a change in the meaning of the notions of 'Montenegrin' and 'Serb' identity (Džankić 2013). The political shift culminated at a national referendum on independence held on

2 Relying on expert survey data, Rohrschneider - Whitefield (2009) argued that distributional issues are the most salient issue in the party competition in Slovenia. On the other hand, Vuković (2015: 127) argued that following the crises of the socialist federation "the most salient political issues in the constituent republics became those related to ethnic/national and religious identity". 
21 May 2006 at which Montenegro declared its independence from Serbia and Montenegro (formerly the Federal Republic of Yugoslavia) and renamed itself the Republic of Montenegro (Polity IV Country Report 2010). Here, we arrive at the first big difference between the two countries. As noted, the process of democratic development and nation-state-building was much faster in Slovenia. Regarding the former, Montenegro's independence followed some 15 years later with significant internal opposition and an identity-building process for both Montenegrins and Serbs. With quite a homogenous population, Slovenia was able to resolve its independence claim much quicker and without internal opposition to the idea.

\section{Characteristics and typologies of the party systems in Slovenia and in Montenegro since 1990}

The initial bi-polar systems in post-communist countries (communist vs. anti-communist bloc) evolved in various ways to become bi-, tri- or multi-polar systems (Fink Hafner - Krašovec 2011). This process was followed by the development and changing of patterns in party competition. Among various indicators for analysing changes in party competition patterns (Mair 2006: 65-66), the most useful for the Slovenian case is "whether the government is made up of parties of the same ideological colour or if it allows a wider variety of party ideology within the same ruling coalition" (Fink Hafner - Krašovec 2011: 8). In this regard, the greatest political conflict in Slovenia is ideological in nature, although there have been instances of cross-ideological cooperation. The Slovenian parliamentary system with proportional representation, a relatively low threshold and fairly undemanding requirements to establish a new party (except for rules on the public financing of political parties) has been relatively accessible to new parties. Despite the introduction of stricter rules in 1994, only 200 signatures along with political programme and internal party rules are still needed to set up a new party (Fink Hafner 2001). The Montenegrin system is based on proportional representation as well and has also been quite accessible to new parties (Stankov 2019). The major difference with respect to Slovenia is the primary issue over which parties compete for votes. Unlike the ideological axes of Slovenian party competition, starting in 1997 societal cleavages became axes around which political parties have competed in Montenegro. Parties rely on these cleavage divisions as they fight to represent different ethno-cultural groups, particularly groups based on structural cleavages (religion, language, culture), and recreate them as a catalyst of modern political struggles (Džankić 2013).While Slovenia was transformed into a parliamentary party system after the first multi-party elections in April 1990, Montenegro was for several years struggling to establish a competitive pluralist system. The first serious challenge to the power of DPS arose from a party split in 1997 that saw the creation of 
DPS and $\mathrm{SNP}^{3}$. To reiterate, while both systems have proportional representational systems and loose rules for new parties, they differ in two key respects. First, the Slovenian system is much more competitive and experiences regular shifts in power, while after three decades DPS' domination of the Montenegrin political landscape came to an end in October 2020. Second, Slovenian parties compete along ideological lines while Montenegrin parties are still structuring their competition around ethno-structural cleavages. The following sections detail the developmental paths in these two states.

\section{Development of the party system - Slovenia}

The main characteristics of the Slovenian party system development are focused on the communism vs. anti-communist cleavage. Fink Hafner - Krašovec (2011) analysed the development process starting from the 1992 elections based on the 1991 Constitution which allowed for polarised pluralism with a tri-polar pattern of competition. The party LDS (Liberal Democracy of Slovenia) occupied the metric centre for about a decade. Like in other transition countries, after LDS enjoyed its highest electoral support in 2000 (36.21\% of votes) and a possible position as the dominant party, LDS' electoral support started to decline. The party started to lose its electoral profile and became burdened by clientelism and corruption linked to its long-term position in government. In the period between 1992 and 2008, new small parliamentary parties played an important role in mitigating the population's anti-party sentiments (Fink Hafner 2012). Many things in Slovenia altered in 2008 with the arrival of the first, somewhat bigger new parliamentary party. This process continued at the 2018 elections, with the newcomers even receiving the greatest share of the votes at the 2011 and 2014 elections. Creating expectations that a balance between responsibility and responsiveness ${ }^{4}$ would be restored, the new party system has so far been characterised by either partial or full turnover since some or most new parties have been replaced by newer ones (Haughton - Deegan Krause 2015). This process further raises concerns about instability of the party system itself (Cabada - Tomšič 2016: 44). While analysing the idiosyncrasies of the Slovenian party system's development, Fink Hafner (2006) argued the party system incrementally developed as a "lack of any clear-cut ideological shifts or electoral engineering, as well as a combination of ideological polarisation with broad governmental coalition-building with the same party in the centre was taking

3 The Socialist People's Party

4 Responsibility is defined as the decisions of political parties and leaders that take account of the long-term needs of their people and countries, and the claims of audiences other than the national electoral audience. We can talk about responsiveness when political decisions sympathetically respond to the short-term demands of voters, public opinion, interest groups, and the media (Bardi et al. 2014: 237). 
place for most of the 1990-2004 period, which ended with the 2004 - centre-right electoral victory" (Fink-Hafner 2006; Ramet 2006; cited in Hlousek 2014).

According to Kustec and Henjak (2015), in 1992 the Slovenian Democratic Union split into two parties: the social-liberal wing became the Democratic Party while the conservative faction established the National Democratic Party. A third group, dissatisfied with either option, joined the Social Democratic Party (SDSS, later simplified to SDS), which suffered a clear defeat at the 1992 elections and was barely able to enter the Parliament. Nevertheless, it formed a coalition with the winning Liberal Democracy of Slovenia (the central player in the Slovenian political space) and even became a member of the governing coalition (KustecHenjak 2015). Later on, it became the dominant party of the centre-right under the name Slovenian Democratic Party. In 2004, the electoral loss of LDS was a milestone amid further changes to the Slovenian party system, particularly in dominant pattern of party competition. The 2004 shift towards moderate pluralism brought about bi-polar party competition and the alternation of centre-right and centre-left governments. Legislative elections in October 2004 reversed this trend, with SDS (Social Democratic Party of Slovenia), a right-wing populist party led by Janez Janša, gaining a narrow victory over LDS. SDS took control of the government, in a coalition with NSi (New Slovenia - Christian Democrats as a socially conservative party), SLS (the Slovenian People's Party as a conservative party), and DeSUS (the Democratic Party of Pensioners of Slovenia - mostly centre-oriented with a Pro-European ideology). However, the four biggest parties attract around three-quarters of all votes $(74 \%$ at the last elections in 2008), so small parties are still needed to create government coalitions (Fink Hafner - Krašovec 2011). Despite the relative openness of Slovenia's party system, only a small number of new parties entered the Slovenian Parliament in the first two decades. This trend started to change at the 2008 parliamentary elections, fostered by the rapid decline of LDS, the strengthening of SD as the temporarily strongest party on the left, and the entry of a new parliamentary party that splintered off from LDS (Kustec - Henjak 2015). The processes that ensure an open party competition system (Mair 2006), after the bipolarity visible since 2004, remained malleable and were generally a flexible addition to the established party competition.

Different parties emerged upon the transformation of the League of Communists of Slovenia ${ }^{5}$. At the 2011 and 2014 elections, the party system's insta-

5 Such as the United List of Social Democrats in 1993 and Social Democrats in 2005; the League of Socialist Youth (later the Liberal Democracy of Slovenia); the Socialist League of the Working People (later the Socialist Alliance); the Social Democratic League (later the Social Democratic Party of Slovenia). Simultaneously, the opposition to the old regime, emerging from society, first called the Alliance of Intellectuals and later renamed the Slovenian Democratic Alliance/Union, was established at the end of the 1980s. It included social groups with specific issues at heart, such as religious groups (Slovenian Christian Democrats; Christian Socialists), peasants (the Slovenian Peasant Party - People's Party, later renamed the Slovenian People's Party), pensioners (the Democratic Party of Pensioners), regional parties 
bility reached new heights, with the once-dominant LDS almost completely disappearing from the scene, being supplanted on the broad left first by SD, then by Positive Slovenia (a centre-left political party) and, finally, by the Miro Cerar's Party, later renamed the Modern Centre Party (centre party - social liberalism) (Kustec - Henjak 2015). At the 2018 elections, LMŠ (the List of Marjan Šarec, a centre-right party) entered the Parliament. Except for Zares and the (United) Left, all of these parties were strongly reliant on their party leader (Malčič - Krašovec 2019). Here, Cerar represented the high point of the Slovenian electorate's search for a properly behaving political leader as he claimed to "transcend traditional political and ideological divisions and brought new standards of political culture" (Cabada - Tomšič 2016: 42).

Generally, Slovenia may be defined as having undergone two stages of development: a) the first stage is before full EU membership; and b) the other stage is after full EU membership. In stage one, there were no significant problems in the consolidation of democracy, no significant EU-related cleavages in the national party arena and no direct EU-political pressures on the national party competition (Fink-Hafner 2006). Krašovec, Lajh and Kustec Lipicer (2006) point out the "asymmetrical « Europeanisation effect and changes in parties' organisational structures. The new stage of membership opened up new space for Europe to impact the national party system format and thus EU issues became the main nationally-specific domestic ideological cleavage that triggered certain party struggles (Fink-Hafner 2006).

\section{Development of the party system - Montenegro}

Post-communist parliamentary life began back in 1990 with general parliamentary (and presidential) elections held to determine the new course of politics in Montenegro. Here, the League of Communists of Montenegro, later transformed to the Democratic Party of Socialists (DPS) won an absolute majority in both votes and shares of seats ( $56.18 \%$ and $83 / 125$ seats). This election laid out the path for the uninterrupted electoral domination of DPS that continued for 30 years until the election in October 2020.

However, this does not mean the DPS' power structure was not challenged in this 30-year period. In the first period of transition from 1990 to 1997 (Darmanović 2007), Montenegro (as part of the Socialist Republic of Yugoslavia) was considered to be an authoritarian regime. The regime's nature was reflected in frequent alterations to the electoral rules between elections, most likely as a strategy to consolidate power under the threat of electoral loss. Still,

(e.g. the Alliance of Haloze, Alliance for Primorska, Party of Slovenian Štajerska) and ethnic interests (e.g. the Alliance of Roma, Communita Italiana) (Kustec - Henjak 2015). The DEMOS coalition was created by an agreement between the Slovenian Democratic Union, the Social Democrat Alliance of Slovenia, the Slovene Christian Democrats, the Peasant Alliance, and the Greens of Slovenia. 
considerable democratisation and pluralism arose from the split within the party rather than from the external pressure of other political subjects. Similarly to how Darmanović (2007) describes the 1990-1997 period as the first period of transition, we posit that this is the first period of party system development, characterised by the DPS' dominant position and the lack of any sort of competitive constraints on its political domination.

Džankić (2013) states that 1997 is a crucial critical juncture for determining the country's political course and is the first electoral cycle where serious pluralistic competition can be observed. This critical juncture was opened by revisiting the decision that followed the 1990 general election to remain in a federal state with Serbia. This decision was probably based on the expectation that the communist system which had disproportionally benefited Montenegro vis-à-vis other Yugoslav republics would continue to do so (see Roberts 2007). Some authors argue that precisely the failure to secure such a privileged position in the subsequent years is what inspired the 1997 turn from Milosevic and his regime in Belgrade (Džankić 2013; Vuković - Milačić 2016). This turn ultimately resulted in a party split of DPS into the opponents and proponents of the regime in Belgrade. While the initial point of the division is said to be about political and economic hardship (Vuković - Milačić 2016), the division became salient and shaped the political landscape once it was structured along the Serb-Montenegrin identity divide (Džankić 2013). This is what Džankić (2013) calls the ethno-structural cleavage in Montenegrin politics, namely, the fact that the overriding political conflict is organised along the divide between the Montenegrins and the Serbs ${ }^{6}$.

In the mentioned context of 1997, half the DPS supported the turn to independence under the leadership of Milo Đukanović, while the other part split and created the Socialist People's Party (SNP) led by Momir Bulatović. These events mark the first real challenge to the power of the communist political infrastructure inherited by DPS and the beginning of pluralistic competition based on ethnic cleavages. As noted, the impulse towards pluralism arose from disagreement within DPS and not from an external political subject. The direct political confrontation that followed was extremely close, with Đukanović (DPS) winning the 1997 presidential election over Bulatović (SNP) by a mere 5,488 votes in total $(50.8 \%$ vs. $49.2 \%)$.

This slight electoral advantage may be directly linked to the opening of the party system. Further, the party system's opening and the true introduction of pluralism is reflected in the overall democratisation of Montenegro and recognised as this is the first year in which the Polity IV index considers Montenegro

6 Contemporary political conflict in Montenegro is structured as an ethnic identity cleavage, but cannot be separated from the statehood issue. The statehood issue saw the culmination of the redefinition of Serb and Montenegrin identity and remains at the core of what it means to be a Serb or a Montenegrin in Montenegro. 
to be fairly democratic rather than an authoritarian political system. To reiterate, we can look at 1997 as the end of the first period of the transition (Darmanović 2007) and as the finalisation of the transformation from a one-party system to political pluralism.

The events in 1997 represent a critical juncture in the party system's development, which we argue effectively came to an end in 2002. We posit that the 1997-2002 period is the second stage in the development of the Montenegrin party system, denoted by cleavage-based competition but unstable political partnerships. As mentioned, one part of the critical juncture entailed the formation of political pluralism, while another feature was the process of structuring coalition potential. Here, DPS' struggles to form lasting political partnerships are well illustrated by the 2001 parliamentary elections. For the first and only time, Montenegro was ruled by a minority government as DPS secured just $42 \%$ of the vote and 36/77 seats in parliament. Initially, part of the government, the People's Party, left the coalition as DPS was continuing to push for independence; however, the Liberal Alliance provided a parliamentary majority without entering the government so as to enable the formation of a minority government. The Liberal Alliance's support was made conditional on DPS guaranteeing a new referendum on independence within 1 year. When these political guarantees were not honoured, the Liberal Alliance withdrew its support and snap elections were held in 2002, giving enough time for DPS to consolidate its power. The coalition which formed in 2002 shaped the course of Montenegrin politics for over a decade and marks the third stage of the party system's development (2002-2012). In this period, political issues were still dominated by the cleavage division, but the coalition potential is clearly delineated. DPS has found its political allies in minority parties (Albanian, later Bosniak and Croatian) and the smaller Social Democratic Party of Montenegro (SDP).

The fourth stage in the development may be characterised as certain political processes that failed to have a long-lasting impact on Montenegrin party politics. We are primarily referring to the wave of "new" parties emerging (largely from party splits) between the 2012 and 2016 parliamentary elections that attempted to alter the established patterns of competition. Most notably, new political parties such as Positive Montenegro or Democratic Montenegro tried to shift the focus of the political contest away from ethnic cleavage issues and towards economic issues and sustainable development However, while most 'new' parties were able to secure some representation at the national level, they were unable to break the ethnic division in the coalition-building, failed to challenge the position held by DPS seriously, and did not present economic issues as being politically relevant to the electorate (Stankov 2019). We label this period the fourth stage in the development of the party system in Montenegro.

Two constant features are observable in all stages of the party system's development. First, since 1997, the party competition is organised along the ethno- 
-cultural cleavage with one bloc consisting of Montenegrin and minority parties (pro-independence) and the other of Serbian parties (pro-union). This division clearly structured party competition, contestation issues and coalition-building potential from 1997 up to the independence referendum held in 2006, and we argue that this division is still present and relevant today. Ethnic cleavage divisions are reflected in pro-against independence blocs, while the main point of contestation is the general ethnic identity division. While the statehood issue has obviously shaped the meaning of the identity division and the independence referendum was finalised 14 years ago, the ethnic identity division persists today. Moreover, apart from the statehood issue, ethnic contestation spills over on to policy preferences related to foreign policy alignments, language and church issues, as well as sexual minority rights. The second constant is the electoral supremacy of DPS at the national level which came to an end at the elections in October 2020, prompting some authors to characterise the Montenegrin party system as multiparty with a dominant party.

In summary, we can identify 5 stages in the party system's development: a) the transition from a one-party system to fully-fledged pluralism (1990-1997); b) cleavage competition with unstable political partnerships (1997-2002); c) structured and predictable competition, cleavage persistence and DPS domination (2002-2012); d) the emergence of several new parties and attempt to change the predictability of the party competition, issues, topics and electoral alliances (2012-2016); and e) the reconsolidation and predictability of the party competition (2016 onwards).

\section{Similarities and differences in party system development}

Looking at the two cases together, we detected only one common characteristicthe frequent entry of new political parties. However, while both cases have seen an abundance of new parties since 2008, the coalition-building potential was only altered in Slovenia. Although new parties in Montenegro, such as Positive Montenegro and Democrats, have been successful in rallying up the electoral support, they have been unable to create a significant majority for a government without DPS ${ }^{7}$. Further, the two cases are developing quite different party systems, which we believe reflects the general stages of democratisation of the respective polities. In this regard, the Slovenian party system is more open and has witnessed frequent alternations in power with a government coalition being built around ideological similarities. In contrast, the Montenegrin party system was a pre-dominant party system in which the coalition potential is still

7 The new election results change this conclusion slightly. DPS lost the 2020 October elections, but its coalition-building potential remains the same. Traditional opposition parties won a slight majority to enable the formation of a new government, which had not been formalised at the time of writing this paper. 
structured along ethnic identity cleavage lines. In addition, although we may speak of roughly two stages in the party system development in Slovenia, namely prior to and after EU accession, we identified 5 of such stages in Montenegro. These stages depend on the level of party system institutionalisation and the dominant issues that structure the party competition. Seen together, we believe these differences in the two-party systems reflect the general state of democracy in these countries and demonstrate how democratisation stages are correlated with stages in development of the party system.

\section{The electoral system as a factor in party system characteristics}

Electoral system research often stresses that proportional systems tend to be more open to newcomer parliamentary parties than systems with majoritarian rules. Proportional systems cause less deformation of electoral results and force political parties to collaborate and create a consensual political culture more supportive of democratic developments than majoritarian rules (Fink Hafner Hafner Fink 2009). Although there is a 'chicken and egg' problem with respect to causality, it is generally believed that proportional systems translate shares of electoral votes into representative seats more precisely than other systems (Fink Hafner - Hafner Fink 2009). The general type of electoral system at the national level (see e.g. Selb - Pituctin 2010) may influence the district-level electoral rules (e.g. by getting rid of small parties). The choice of electoral system seems to follow what may be called the 'Micro-mega rule' (Colomer 2004), by which the large prefer the small and the small prefer the large (a few large parties tend to prefer small assemblies, small district magnitudes and rules based on small quotas of votes for allocating seats, while multiple small parties tend to prefer large assemblies, large district magnitudes, and large quota).

Juberías (2004) explained "the model of transition towards democracy in the following three patterns: 1 . In countries whose democratic transitions were characterized by a sudden and revolutionary breakaway with the past and which therefore held their first free elections under the supervision of the former oppositional organisations, a basically proportional representation electoral system was chosen; 2 . In countries where the transition to democracy was carried out by means of negotiation, usually between the opposition forces and the more liberal sectors of the single Party - the option was a mixed electoral system, combining both proportional and majoritarian elements. Slovenia fits this pattern - elections took place under Communist apparatus control, although the democratic opposition was strong enough to impose its point of view on a significant number of aspects and to somehow scrutinize the entire process; 3. In countries where opposition was practically non-existent or very weak and disorganized until the actual moment of the elections, the organisation of these fell undisputedly into the hands of the Communist Party apparatus 
and therefore they were held using the traditional majority system - which most Communist officials felt was best suited for them". Therefore, the electoral rules in post-communistic countries are extremely important.

Slovenia has a proportional electoral system. Elections are regularly held every 4 years upon the expiry of the term of the parliament, while early elections are organised when the National Assembly is dissolved during the 4-year parliamentary term. Candidates may be proposed by political parties or voters. The country is divided into 8 electoral units for elections to the National Assembly. Each unit is divided into 11 districts; accordingly, each unit returns 11 deputies (DVK 2020). The principle enshrined in law is that one candidate is elected for each electoral district. Special electoral units have been formed to serve those areas in which the Italian and Hungarian national communities reside. This principle is the voting right exercised by members of the Italian and Hungarian national communities ${ }^{8}$ (DVK 2020).

Although it seems there are relatively many districts (11), in real life competition among political candidates occurs at a lower level and is closer to a majoritarian system.

One may say that the parliamentary threshold has remained very low, albeit it has slightly increased. Up until 2000, it was three mandates/seats or approximately 3.3\%, although since 2000 under the National Assembly Elections Act the election threshold has been set at $4 \%$. Whether a party has reached that threshold is determined by the National Electoral Commission when the seats are being apportioned. In 2000, the electoral formula was also altered on two levels: a) within an electoral unit, seats are apportioned using the Droop quota $^{9}$; and b) at the national level, seats are apportioned using the D'Hondt method. Candidates who receive the highest number of votes as a proportion of the total number of votes in the electoral districts in which they stood are elected from the list of candidates (relative to the seats received) (DVK 2020). Voters may only opt for that candidate from the list who stood for election in their voting district. Until 2000, only parliamentary parties were entitled to this provision. After several attempts to change the rules and after Constitutional Court decisions in 1999 and 2002, all parties gaining at least 1\% of votes at elections become entitled to such public subsidies (Krašovec - Haughton 2011).

We may conclude that Slovenia's electoral system and proportional representation has a relatively low threshold and fairly undemanding requirements to establish a new party. Even though the rules for the public financing of political parties pose an obstacle, in general the Slovenian system can be defined as being relatively open to new parties.

8 Each community is represented by one deputy in the National Assembly, with the members of these communities being entitled to vote for other National Assembly deputies as well.

9 On the district level, the Hare quota was used until 2000, but was later replaced by the Droop quota (Krašovec 2007). 
In comparison, Montenegro's electoral system is largely a proportional representation system that has seen several iterations over the years. Changes here usually consisted of redrawing electoral units, the electoral threshold and minority representation rules between elections. Further, these changes have acted to ensure DPS enjoys electoral domination and that potential coalition partners will enter the parliament and limit the reach of the opposition bloc. Whenever the power of DPS was threatened even in the slightest, in 1992, 1997 and 2001, the system was altered to enable deinstitutionalisation of the party system and to give greater space for either minority representation (Albanian ethnic parties) or small parties (Liberal Alliance). In this way, democratisation proceeded, but firmly guided by the threat of losing power to the unionist opposition bloc.

The electoral rules were fixed after the referendum and have remained largely unchanged since $2007^{10}$. The referendum campaign showed that DPS was no longer in a position to single-handedly form a government. Instead, it would need to enter coalition agreements to stay in power. This coalition-building potential was structured along these ethno-structural cleavages so that parties in support of independence were a natural partner of DPS. While governmental coalitions since 2006 reflect a pro-independence bloc, the point of political contestation expanded to a broad spectrum of identity issues found in the ethno-structural divide between the Serbs and Montenegrins. Apart from the Social Democratic Party, the rest of the coalition bloc was created from Croatian, Albanian and Bosnia ethnic parties ${ }^{11}$.

This reliance on minority parties is leading for the first time to a fixed Montenegrin parliamentary structure with 81 seats and electoral rules which enable minority parties to enter the parliament under affirmative-action rules. According to the Article 94 of the Electoral Law, minority parties are exempt from the $3 \%$ electoral threshold and are required to separately win at least $0.7 \%$ of votes for a seat allocation of up to 3 members of parliament (MP). If they do not win at least $0.7 \%$, a minority party can still be awarded 1 MP position by winning $0.35 \%$, a stipulation introduced specifically for the Croatian minority group. In other words, for their support of Montenegrin independence minority parties have gained almost guaranteed representation and formed every coalition government in Montenegro ever since. Further, Article 13 of the 2007 Constitution states that the languages for official use are Bosnian, Croatian and Albanian. This right is further reinforced in Article 79 that lists specific minority rights, including public use of national symbols, state-based aid for cultural and religious associations, and dual-language use in municipalities with the

10 Later changes to the electoral law include the introduction of gender quotas, but they do not change the key features of the electoral system (district magnitude size, electoral formula, and threshold, number of seats or ethnic minority representation rules).

11 According to the latest census in 2011 , Croatians made up $0.97 \%$ of the population, while Albanians accounted for $4.91 \%$ and Bosniaks $8.65 \%$ (excluding an additional 3.31\% of Muslims as an ethnic category). 
significant presence of a minority population. With respect to our core argument, this demonstrates how the threat of losing the dominant position in the party system along with the threat of deinstitutionalisation have opened space for democratic progress and the inclusion of minority opinions and representation.

To summarise the above, the electoral systems of Slovenia and Montenegro are quite different. While they are both proportional representation systems, the Slovenian system allows preferential voting and is divided into multiple districts and electoral units. On the other hand, Montenegro has a single-unit electoral district for the entire country. In that sense, the Montenegrin system is the simplest form of proportional representation, while the Slovenian one approximates majoritarian competition on the electoral-unit level. Second, the threshold levels also vary (3\% and $4 \%)$ and Montenegro has introduced many more provisions dedicated to minority party representation. While we are unable to draw causal conclusions, we note the electoral system differences made to the party system arena at least in terms of the nature of the party competition. The Slovenian preferential vote could be argued to increase the responsiveness and responsibility of officials who are elected and related to a volatile electorate and unstable party system, as shown in the previous section. The electoral system of Montenegro not only fosters ethnic minority representation, but is witness to the dominance of ethnic voter-party linkages in the entire system. With these permanent voter characteristics being in the focus of the party competition, the closed nature of the Montenegrin party system is not surprising.

\section{Quantitative measures of the party systems - fragmentation processes and and a comparative analysis of the volatility of the case studies}

Post-communist party systems are characterised by considerable fragmentation $^{12}$, high volatility as well as low trust in parties and parliaments (Lewis 2001; Jungerstam Mulders 2006; Rose 2009). The latter translates into relatively widespread anti-party sentiments (Fink Hafner 1994).

While analysing the stages of developing a democracy and the transition, we used two quantitative indicators - the index of electoral volatility and the index of the effective number of parties. Regarding the latter, the effective number of political parties shows in which ways party systems are fragmented. The fragmentation of a party system is an important indicator of a low level of institutionalisation, although causality cannot be inferred among these phenomena (Jurek 2010).

At the beginning, the Slovenian party system was "mainly bipolar" (Fink Hafner 2006), structuring the competition among centre-left parties and a clus-

12 Compared to older Western party systems. 
ter of new (largely centre-right) parties. Further, it was quite fragmented - the average effective number of parties for the 1990-2004 period is 6.5 (Fink Hafner 2006), while an increase follows after 2008. The Slovenian party system shows a tendency for a progressive concentration of party competition. Looking at the entirety of the democratic competition, the effective number of parties has been continually declining from almost 9.0 in 1990. Nevertheless, Slovenia has a fragmented party system.

\section{Figure 1: Effective number of parties by electoral year in Slovenia and Montenegro $^{13}$}

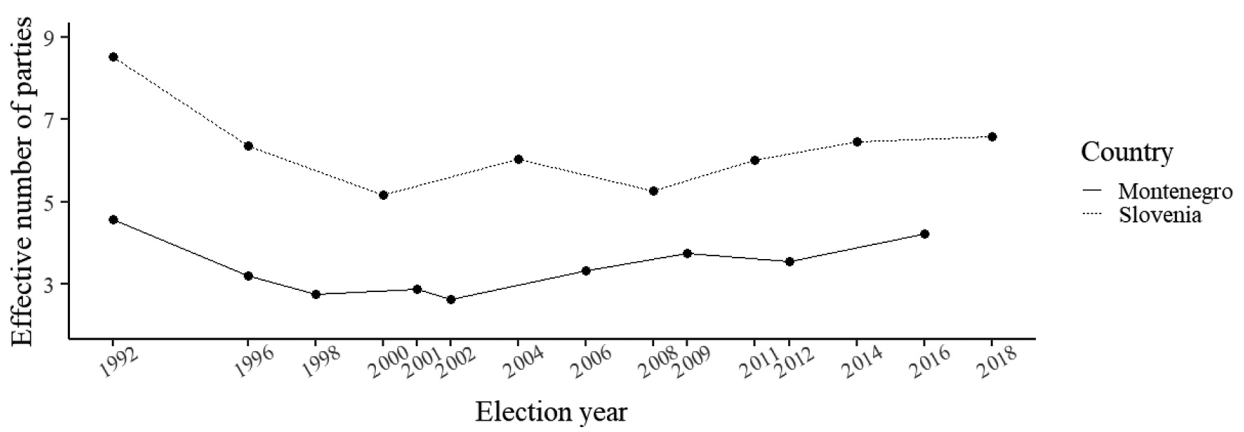

Source: Slovenia: Own calculations based on results of the National Electoral Commission (DVK 2020); Montenegro: Own calculations based on vote shares (Laakso - Taagepara 1979)

Regarding Montenegro, this paper has briefly shown that the salient political conflict is the ethno-structural cleavage between the Serbs and the Montenegrins. Reliance on this cleavage as the main source of political confrontation is perhaps what makes Montenegro "one of the most closed party systems in Europe" (Enyedi - Bertoa 2018). Here, two blocs are in competition and the crossing of ethnic cleavage lines in terms of coalition-building is very unlikely. The first bloc consists of DPS, small Montenegrin parties and ethnic minority parties, and coincides with a standard formula for government formation since 2002. On the other hand, Serbian parties and small civic parties form the second bloc. In one occurrence, the civic party Positive Montenegro entered a coalition with DPS despite having clearly promised during the election not to do so, the decision led to the party's dissolution and disappearance from the Montenegrin political scene. In the section below, we show that voters indeed perceive the party competition to be structured in such a way that limits volatility within the

13 Differences may arise if share of seats in the parliament is used instead. However, since the number of seats was changed multiple times in the time frame analysed, we decided on the absolute vote shares at the parliamentary elections. 
party blocs.Looking comparatively at the average effective number of electoral (ENEP) parties in Slovenia and Montenegro, it is evident that Slovenia still has a fragmented party system while the party system in Montenegro is much more closed. The average effective number of parties is almost less than half than that in Slovenia, indicating that the differences in dominant and salient political issues (i.e. ideology vs. ethnic cleavages, respectively) have probably also been translated and reflected in the balance of power and coalition-building potential in the party system.

\section{Figure 2: Average effective number of electoral (ENEP) parties in Slovenia and Montenegro (1990-2016)}

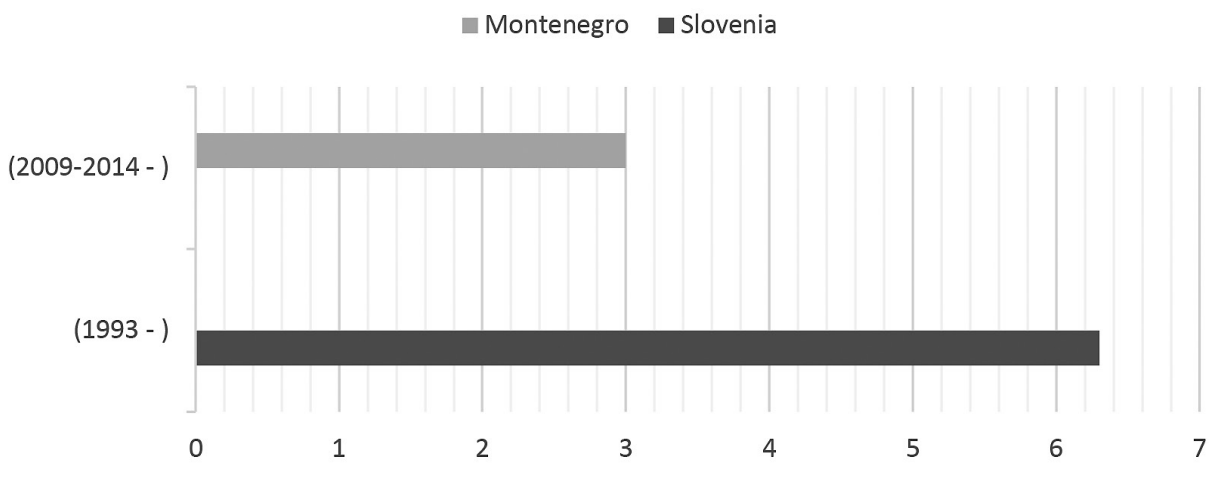

Source: Enyedi - Bertoa (2018)

With respect to the other measure of party system stability, volatility has traditionally been used as a measure of a party system's institutionalisation (Mainwaring - Torcal 2006). Considerable electoral volatility signifies a fluid political environment and thus a lower level of institutionalisation of the party system (Bielasiak 2002:198-206). A low level of electoral volatility reveals close links between parties and society, which might indicate a low level of democratic development. Understanding this linkage is critical since political parties should be viewed as a fundamental component of democracy (Jurek 2010).

In our specific cases, volatility in Slovenia remained comparatively high (above 30\%) after the first elections in 1992 (Fink Hafner et al. 2017). This was mainly due to the party consolidation processes that brought about the disintegration and merging of smaller, mainly left-wing political parties. As a stronger bipolar pattern of party competition emerged, volatility declined and was at its lowest (23\%) in 2004 when a coalition was formed the right-wing parties for the first-time since Slovenia's independence (Fink Hafner et al. 2017). Volatility then rose again at the 2008 elections in which new (largely left-wing) political parties were established and the level of volatility further rose to $50 \%$ in 
2014, although these new parties completely failed at the subsequent elections (Kustec-Henjak 2015).

\section{Figure 3: Volatility - parliamentary elections in Slovenia and in Montenegro ${ }^{14}$}

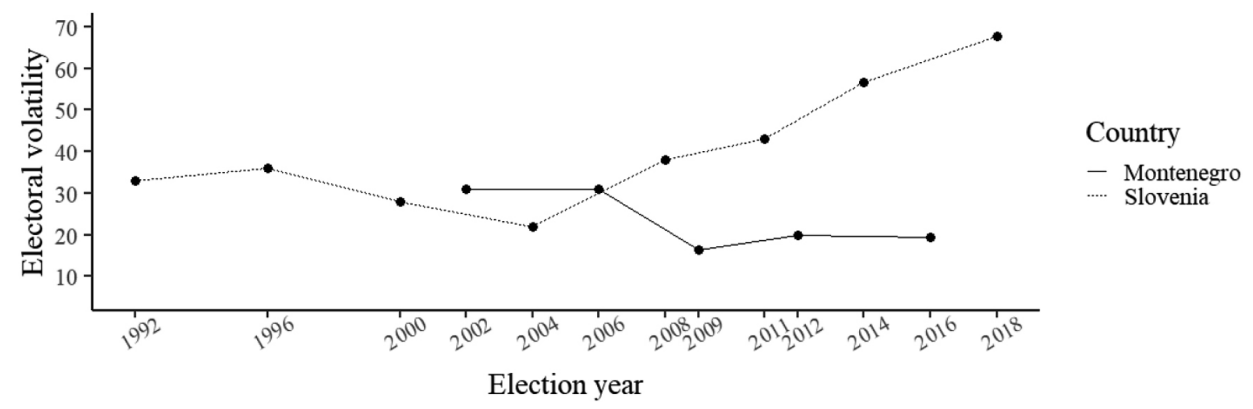

Source: Slovenia: Own calculations based on results of the National Electoral Commission (DVK 2020); and Enyedi - Bertoa (2018); Montenegro: for 2001-2002 and 2002-2006 (Powell - Tucker, 2014). The values represent the mean electoral volatility for 3 electoral cycles (including 2006-2009). For 2006-2009; 2009-2012; 2012-2016 (see Kapidžić - Komar 2019).

In general, volatility in Slovenia has risen significantly. The starkest finding is that with the end of LDS' dominance of the political scene, voters supporting the broad left side of the political spectrum shifted their support from LDS to SD, then to PS, then to SMC (Kustec - Henjak 2015) and finally to LMŠ. It is interesting that SDS managed to win the support of almost one-third of the electorate between 2004 and 2011, only to witness the demobilisation of about one-third of its voters at the 2014 elections while still retaining its status as the second-largest party in the context of the significantly lower turnout (Kustec - Henjak 2015). Evidence of cleavage-based politics reflected in patterns of electoral volatility is clearly visible in Montenegro. Electoral volatility in Montenegro has been found to be one of the lowest among post-communist societies (Tavits 2005; Powell - Tucker 2014), yet it is on the rise in the last few years ${ }^{15}$. However, in a recent working paper Kapidžić and Komar (2019) showed that the rising volatility rate, averaging out at $19.3 \%$, is still on average much lower than in other Eastern European countries (Bértoa - Deegan Krause - Haughton 2017) and is primarily occurring within bloc. Within-bloc volatility (Bartolini - Mair 1990) means that voters change their choices but

14 Due to the very fragmented nature of the party system in the 1990s, it is impossible to calculate a reliable value for volatility levels. This is a consequence of many new parties forming and disappearing after one electoral cycle as well as frequent electoral coalitions between diverging party families making it hard to disentangle the actual electoral result of certain parties at specific elections.

15 Note that Powell and Tucker (2014) attribute most of the volatility in Montenegro to the emergence of new parties, a feature discussed earlier in this article. 
only within their ethnically limited bloc of parties (Kapidžić - Komar 2019). In other words, even when voters are changing their electoral choice, the choice is still confined to either the pro or against independence bloc. Almost all of the volatility, $13.98 \%$ (out of 19.3\%) is within-bloc (Kapidžić - Komar 2019), supporting the notion that Montenegro is the most closed party system in Eastern Europe (Enyedi - Bertoa 2018). In general, it is believed that party volatility strongly affects the elite-mass linkage and stabilisation of the party system in new democracies, as well as parliamentary recruitment and elite formation (Semenova et al. 2014). A party system is more likely to become unstable due to irregular and erratic elites than the lack of a strong political identity among voters (Tavits 2008). With a preferential vote system that fosters individual competition within the parties themselves, this pattern is relatively obvious when we consider the frequent alternations of parties and party leadership in Slovenia. At the same time, the Montenegrin system remains relatively stable in this regard. Although no causal inferences can be drawn, voter-party linkages based on stable voter features like ethnic identities limit the potential for individual vote shifts. In addition, here we are somewhat constrained in the time comparison of the electoral volatility in Slovenia and Montenegro since no reliable data could be found prior to 2006 in Montenegro $^{16}$.

\section{Figure 4: Average electoral volatility in Slovenia and Montenegro (post-communist European democracies, 1990-2016)}

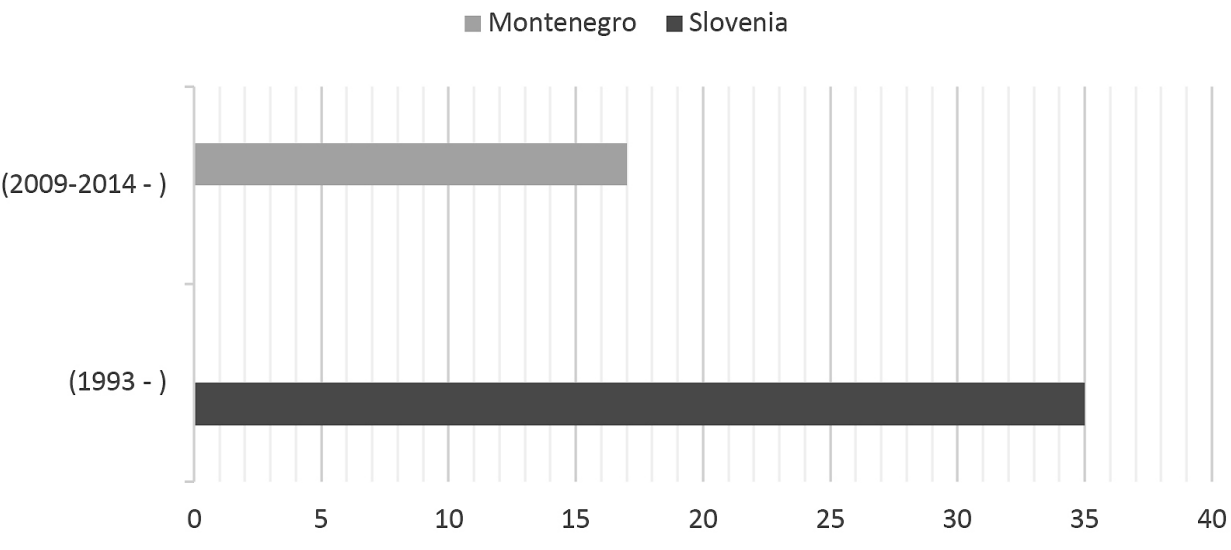

Source: Enyedi - Bertoa (2018)

16 Different pre-electoral coalitions make it quite difficult to distinguish individual party performance from election to election. 


\section{Conclusion}

In this special issue, our article offers a comparative approach to assessing the quality of democracy in specific areas like party system development and differences in democratisation processes in two case studies - Slovenia and Montenegro, after the breaking up of Yugoslavia.

Different internal and external factors in Slovenia and Montenegro are correlated with the quality of democracy in the case studies. To explain internal factors such as: the transformation of the 'old ruling elites', creation of 'new political parties', ideological cleavages, the fragmentation processes, volatility and electoral rules, we applied a descriptive and quantitative approach between 1990 and 2018, presenting the party system structure in the two case studies and the speed and stability of the democratic consolidation. Even though both countries were members of SFRY, after its disintegration Slovenia enjoyed a faster, easier and 'smoother' path on its way to establishing a democracy, a stronger economy and greater homogeneity compared to the drawn-out process of democratic consolidation, crises of identity, nationalism, involvement in war, and much slower economic development seen in Montenegro.

On the other side, there are also different external factors like the year of independence, joining NATO, EU-integration status and involvement in war that probably led to higher scores for Slovenia than Montenegro for the indexes of the quality of democracy (see the introduction part of this special issue).

Analysing democratic development processes, we explored the linkages between a faster and more in-depth democratic transition that is followed by effective political competition, shown by both the effective number of parties and the willingness of voters to punish or reward parties at elections. While on the one hand Slovenian politics at the start was structured along the communist-noncommunist divide, it later elaborated a system in which parties compete on actual ideological platforms, with a higher number of parties and a more fluid electorate. This competitive environment probably contributed to the faster transformation from the 'old ruling elites' and establishment of democratic practices. In comparison, the ethnic cleavage-based competition in Montenegro quickly replaced the communist-noncommunist divide in a system that has limited the speed of the democratisation process.

Moreover, the differences in terms of the democracy created and the diverging bases of political competition, ideology and ethnicity are complemented by varying strategies these systems use to rally political support. Clientelism and illicit strategies backfired in Slovenia and were followed by the alternation of power in 2000, while some might argue that in Montenegro they are precisely the mechanism that produced the dominant party system (Džankić - Keil 2017). In Slovenia, these internal developments are seen in the strengthened democracy, diffused power across several political parties, and greater resil- 
ience towards global de-democratisation challenges. On the other hand, we showed that challenges to the power of DPS in Montenegro are correlated with the improved position of minority parties whose support is almost inevitably required in the government formation process. Here, ethnic bases of politics and reliance on minority support are what provides a cordon sanitaire against de-democratisation processes.

With special emphasis on electoral rules and party system developments, as well as the very different fragmentation and index of volatility in Slovenia in comparison with Montenegro, this article has moved one step closer to explanations stating that the party competition and party system development in the two case studies differ not only in the political contexts, but especially in the course of the stages of democratisation.

\section{References}

Bardi, Luciano - Bartolini, Stefano - Trechsel, Alexander (2014): Responsive and Responsible? The Role of Parties in Twenty-First Century Politics. West European Politics 37 (2): 235-252.

Bartolini, Stefano - Mair, Peter (1990): Policy competition, spatial distance and electoral instability. West European Politics 13 (4): 1-16.

Bértoa, Fernando Casal - Deegan Krause, Kevin - Haughton, Tim (2017): The volatility of volatility: Measuring change in party vote shares. Electoral Studies 50: 142-156.

Bielasiak, Jack (2002): The Institutionalization of Electoral and Party Systems in Postcommunist States. Comparative Politics 34 (2): 189-210.

Cabada, Ladislav - Tomšič, Matevž (2016): The Rise of Person-Based Politics in the New Democracies. The Czech Republic and Slovenia. Politics in Central Europe 12 (2): 29-50.

Colomer, Josep, M. (2004): The Strategy and History of Electoral System Choice, in Colomer, Josep, M., eds., Handbook of Electoral System Choice, 3-78, Palgrave Macmillan, London.

Darmanović, Srđan (2007): Montenegro: A miracle in the Balkans? Journal of Democracy 18 (2): 152-159.

DVK (2020): National Election Commission (Državna volilna komisija): available at: https://www. dvk-rs.si/index.php/si/volitve/drzavni-zbor-rs (8. February 2020).

Džankić, Jelena (2013): Cutting the mists of the Black Mountain: Cleavages in Montenegro's divide over statehood and identity. Nationalities Papers 41 (3): 412-430.

Džankić, Jelena - Soeren Keil. 2017. State-sponsored populism and the rise of populist governance: the case of Montenegro. Journal of Balkan and Near Eastern Studies 19 (4): 403-418.

Enyedi, Zsolt - Casal Bértoa, Fernando (2018): Institutionalization and de-institutionalization in post-communist party systems. East European Politics and Societies 32 (3): 422-450.

Fink Hafner, Danica - Hafner Fink, Mitja (2009): The determinants of the success of transitions to democracy. Europe-Asia studies 61 (9): 1603-1625. 
Fink Hafner, Danica - Krašovec, Alenka (2006): Ideološko-politički rascjepi u slovenskoj stranačkoj areni poslije 1989 godine, in Fink Hafner, Danica - Pejanovič, Mirko, eds., Razvoj političkog pluralizma u Sloveniji i Bosni i Hercegovini, 71-99, Fakulteta za družbene vede, Fakultet političkih nauka u Sarajevu, Ljubljana, Sarajevo.

Fink Hafner, Danica - Krašovec, Alenka (2011): The stability of the Slovenian party system: reasons for the success or failure of new parties: available at: http://www.ecprnet.eu/MyECPR/ proposals/reykjavik/uploads/papers/463.pdf (6 February 2020).

Fink Hafner, Danica - Kustec Lipicer, Simona - Čehovin, Gregor - Železnik, Ana (2017): Slovenia's Parliamentary Elite: Representation and Accountability Since 1992. Teorija in praksa 54 (special issue): 60-79, 158.

Fink Hafner, Danica (1994): Antistrankarsko občutje ob demokratičnem prehodu: Slovenija v primerjavi z drugimi postsocialističnimi državami, in Toš, Niko, ed., Slovenski izziv II.: rezultati raziskav javnega mnenja 1992-1993, 181-204, Fakulteta za družbene vede, IDV, Center za raziskovanje javnega mnenja in množičnih komunikacij, Ljubljana.

Fink Hafner, Danica (2001): Politične stranke. Založba FDV, Ljubljana.

Fink Hafner, Danica (2005): Evropske volitve 2004 v Sloveniji - učinkovitost volilnega inženirstva v korist bolj uravnotežene zastopanosti spolov, in Krašovec, Alenka, ed., Volitve v evropski parlament: res drugorazredne volitve?, 107-129, Fakulteta za družbene vede, Ljubljana.

Fink Hafner, Danica (2006): Slovenia: Between Bipolarity and Broad Coalition-building, in Jungerstam Mulders, Susanne, ed., Post-communist EU Member States: Parties and Party Systems, 203-231, Ashgate, Aldershot, Burlington.

Fink Hafner, Danica (2012): Značilnosti razvoja strankarskega sistema v Sloveniji, in Prunk, Janko Deželan, Tomaž, eds., Dvajset let slovenske države, 193-213, Aristej, Ljubljana.

Fukuyama, Francis (1992): The End of History and the Last Man, Macmillan, Inc. Free Press, New York.

Haughton, Tim - Deegan Krause, Kevin (2015): Hurricane Season. Systems of Instability in Central and East European Party Politics. East European Politics and Societies and Cultures 29 (1): 61-80.

Hloušek, Vít (2006): The limited Role of Electoral Game Rules: the Austrian Party System in "Post-Rokkanian" Settings. Politics in Central Europe 2 (1): 24-40.

Juberías, Carlos, Flores (2004): Eastern Europe: General overview, in Colomer, Josep, M., Hand-book of Electoral System Choice, 309-332, Palgrave Macmillan, London.

Jungerstam Mulders, Susanne, ed. (2006): Post-Communist EU Member States: Parties and Party Systems, Routledge, London.

Jurek, Petr (2010): The Institutionalization of Party Systems - Bulgaria, Romania, Croatia and Slovenia in a Comparative Perspective. Politics in Central Europe 6 (1): 110-123.

Kapidžić, Damir - Komar, Olivera (2019): Segmental volatility in ethnically divided societies: (re) accessing party system stability, Working paper.

Krašovec Alenka - Lajh, Damjan - Lipicer Kustec, Simona (2007): The European Union and Party Politics in Slovenia: An Apparent or Real Impact?, In Lewis, Paul G. - Mansfeldová, Zdenka, 
eds, The European Union and Party Politics in Central and Eastern Europe, 169-189, Palgrave Studies in European Union Politics, Palgrave Macmillan, London.

Krašovec, Alenka - Haughton, Tim (2011): Money, Organization and the State: The Partial Cartelization of Party Politics in Slovenia. Communist and Post-Communist Studies 44 (3): 199-209.

Krašovec, Alenka (2007): Volilne študije, Fakulteta za družbene vede, Ljubljana.

Kustec, Simona - Henjak, Andrija (2015): Changing Dynamics of Democratic Parliamentary Arena in Slovenia: Voters, Parties, Elections. Complex Parliaments in Transition: Central European Federations Facing Regime Change 55 (3): 84-104.

Laakso, Markku - Taagepera, Rein (1979): “Effective" Number of Parties: A Measure with Application to West Europe. Comparative Political Studies 12 (1): 3-27.

Lewis, Paul, ed. (2001): Party Development and Democratic Change in Post-Communist Europe. The First Decade, Frank Cass \& Co Ltd, London, Portland.

Linz, Juan J. -Stepan, Alfred C. (1996): Problems of Democratic Transition and Consolidation: Southern Europe, South America, and Post-Communist Europe, Johns Hopkins University Press, Baltimore.

Mainwaring, Scott - Torcal, Mariano (2006): Party system institutionalization and party system theory after the third wave of democratization. Handbook of party politics 11 (6): 204-227.

Mair, Peter (2006): Party System Change, in Katz, Richard S. - Crotty, William J., eds., Handbook of Party Politics, 63-73, Sage, London.

Malčič, Matevž - Krašovec, Alenka (2019): New Parties and Democracy in Slovenia. Politics in Central Europe 15 (1): 115-137.

Nacevska, Elena - Fink Hafner, Danica (2019): Change in The Party System from Liberal- to Ethnic-Based Polarisation - The Case of Macedonia. Teorija in Praksa 56 (1): 7-29.

Nacevska, Elena (2018): Women in Politics in Western Balkan Countries, Faculty of Social sciences, Ljubljana.

Polity IV Country Report (2010): Montenegro: available at: https://www.systemicpeace.org/ polity/Montenegro2010.pdf (4 January 2020).

Powell, Eleanor Neff - Tucker, Joshua A. (2014): Revisiting electoral volatility in post-communist countries: New data, new results and new approaches. British Journal of Political Science 44 (1): 123-147.

Pridham, Geoffrey (2003): Democratization in Central and Eastern Europe: A Comparative Perspective, in White, Stephen - Lewis, Paul G. - Batt, Judy, eds., Developments in Central and Eastern European Politics, 161-173, Duke University press, Durham.

Ramet, Sabrina P. (2006): The Three Yugoslavia's: State-Building and Legitimation, 1918-2005, Bloomington, Ind. \& Washington D.C., Indiana University Press \& The Wilson Center Press.

Roberts, Elizabeth (2007): Realm of the Black Mountain: a history of Montenegro, Cornell University Press.

Rohrschneider, Robert - Stephen Whitefield (2009): Understanding cleavages in party systems: issue position and issue salience in 13 post-communist democracies. Comparative Political Studies 42 (2): 280-313. 
Rose, Richard (2009): Understanding Post-Communist Transformation. A Bottom-up Approach, Routledge, London, New York.

Selb, Peter - Pituctin, Sandrine (2010): Methodological issues in the study of new parties' entry and electoral success. Party Politics 16 (2): 147-170.

Semenova, Elena - Edinger, Michael - Best, Heinrich, eds. (2014): Parliamentary Elites in Central and Eastern Europe: Recruitment and Representation, Routledge, New York.

Stankov, Nemanja (2019): Springing up like mushrooms after the rain: "New" parties in Montenegro's institutionalised party system. Politics in Central Europe 15 (1): 163-185.

Tavits, Margit (2005): The development of stable party support: Electoral dynamics in post-communist Europe. American Journal of political science 49 (2): 283-298.

Tavits, Margit (2008): On the Linkage between Electoral Volatility and Party System Instability in Central and Eastern Europe. European Journal of Political Research 47 (5): 537-555.

Vuković, Ivan - Milačić, Filip (2016): Die Verfassung Montenegros. OER Osteuropa Recht 62 (3): 339-351.

Elena Nacevska, PhD, is the Senior Researcher at the Faculty of Social Sciences, Center for Political Science Research, University of Ljubljana, Slovenia, email: elena. nacevska@fdv.uni-lj.si.

Nemanja Stankov is the PhD candidate at the Doctoral school of Political Science, International Relations and Public Policy, Central European University, Budapest, and Teaching Assistant at the Faculty of Political Sciences, University of Montenegro, email:nemanjas@ucg.ac.me. 